\title{
RESEARCH PAPER \\ Effect of substrate on the in vitro protein digestibility of extracts generated by Saccharomyces cerevisiae
}

\author{
Alejandro Velásquez, and Rodrigo Arias \\ Escuela de Agronomía, Facultad de Recursos Naturales, Núcleo de Investigación en Producción \\ Alimentaria, Universidad Católica de Temuco. Manuel Montt 56, Temuco, Chile.
}

\begin{abstract}
A. Velásquez, and R. Arias. 2013. Effect of substrate on the in vitro protein digestibility of extracts generated by Saccharomyces cerevisiae. Cien. Inv. Agr. 40(3): 503-511. The in vitro crude protein $(\mathrm{CP})$ digestibility $\left(\mathrm{D}_{\text {ivcp }}\right)$, true protein digestibility $\left(\mathrm{D}_{\mathrm{tp}}\right)$ and degradation rate $\left(k d_{c p}\right)$ were measured in different protein extracts of Saccharomyces cerevisiae $(S c)$ yeast. These extracts were generated through a biotechnological method (solid state fermentation). Wheat straw (TWS), barley straw (TBS), chili stubble (TCS), oats hull (TOH) and starchglucose powder (TSP; control) were used as substrates for fermentation by $S c$, and their effect on the aforementioned kinetic parameters in the generated cellular biomass was evaluated. In $12 \mathrm{~mL}$ cultivation medium, $2 \mathrm{~mL} \mathrm{Sc}$ solution inoculum $\left(6.7 \times 10^{6}\right.$ spores $\left.\mathrm{mL}^{-1}\right)$ was added together with $2 \mathrm{~g}$ vegetable substrate (dry) and additional nitrogen source, and the mixture was incubated for 7 days at a constant temperature $\left(26^{\circ} \mathrm{C}\right.$ at $\left.\mathrm{pH} 5\right)$ under aerobic conditions. The average CP content of the yeast biomass (DM) was of $45 \%$. The $\mathrm{D}_{\text {ivcp }}$ and $\mathrm{D}_{\mathrm{tp}}$ were analyzed (two phases: pepsin/trypsin-pancreatin) after the extraction of the yeast biomass, and an effect of the fermented substrate on these values ( $\mathrm{P} \leq 0.001$ and $\mathrm{P} \leq 0.01$, respectively) was observed. The greatest digestibility $\left(\mathrm{D}_{\text {ivcp }}\right)$ was obtained with TSP $(78.9 \% \mathrm{CP})$ and the lowest with TCS $(67.1 \% \mathrm{CP})$. In addition, differences in the $k d_{c p}$ between the treatments were also observed ( $\mathrm{P} \leq 0.01)$. The high contents of $\mathrm{CP}, \mathrm{D}_{\text {ivcp }}\left(71.8 \%\right.$ on average) and $k d_{c p}\left(16.4 \% \mathrm{~h}^{-1}\right.$ on average) suggest that $S c$ yeast biomass has the potential to become an alternative for the production of animal protein supplements.
\end{abstract}

Key words: In vitro protein digestibility, protein extract, Saccharomyces cerevisiae, vegetable substrates.

\section{Introduction}

Saccharomyces cerevisiae $(S c)$ can be used to produce protein concentrates with a high content of crude protein (CP) and a good biological value. Another important characteristic of Sc is that it does not produce mycotoxins. Therefore, these protein

Received May 15, 2013. Accepted August 12, 2013.

Corresponding author: avelasquez@uct.cl concentrates of yeast origin may be considered alimentary alternatives for the supplementation of essential amino acids (besides vitamins and minerals) to animals (Ghaly et al., 2005; Ferreira et al., 2010; Jung et al., 2010; Winkler et al., 2011). Another important aspect to consider in establishing the nutritional value of a concentrate is the digestibility of their proteins (NRC 2001; Ghorai et al., 2009; Nakornpanom et al., 2010). There is no 
information on the dynamic digestion of proteins in yeast biomass. In this trial, the digestibility of a yeast protein concentrate was measured and considered for non-ruminant animals and was expected to be comparable to the digestibility of current protein supplements of high nutritional quality $(>75 \%)$. This hypothesis is based on the low average $\mathrm{CF}(2.9 \% \mathrm{DM}), \mathrm{ADF}(5.9 \% \mathrm{DM})$ and ADIN (3.6\% CP) observed in the biomass of Sc (determined in our laboratory). It should be noted that the digestibility of the nitrogenous fractions of a feed is generally high, except in those feeds that contain more refractory polypeptides, such as insoluble proteins or polypeptides with a low affinity for or susceptibility to proteases; those which are polymerized or chemically bonded to other constituents of the vegetable cell wall; those that interact with tannins; and those that are retained by heating through Maillard's reaction (Riasi et al., 2008). However, the effect of $S c$-fermented substrates on the protein digestibility of the generated yeast biomass is not known. The fermentation by this yeast of different fibrous substrates (waste from crops and the local agro-industry) or of a rapid fermentation substrate (starch-glucose) could generate protein concentrates that vary in their chemical composition, which could translate into a variation in the extent and digestion rate of the proteins. This fermentation would be related to biochemical strategies for bioenergetic efficiency and use carbon skeletons and nitrogen sources from yeast for protein synthesis (Najafpour, 2007; Golfinopoulos et al., 2011).

Accordingly, the objective of this research was to evaluate the effect of type of vegetable substrate fermented by $S c$ on the in vitro protein digestibility of the generated cell biomass.

\section{Materials and methods}

\section{Biotechnological process}

Protein concentrates were produced by $S c$ yeast from the fermentation of five different vegetable substrates. The effect of these substrates on the in vitro $\mathrm{CP}$ digestibility $\left(\mathrm{D}_{\mathrm{ivcp}}\right)$, in vitro digestibility of $\mathrm{CP}$ at $2 \mathrm{~h}\left(\mathrm{D}_{\mathrm{iv} 2 \mathrm{~h}}\right)$, true protein digestibility $\left(\mathrm{D}_{\mathrm{tp}}\right)$ and hydrolysis rate of $\mathrm{CP}\left(k d_{c p}\right)$ in the generated yeast biomass was measured. The yeast protein concentrates were generated via a solid state fermentation biotechnological method (Jay, 2000; Mitchell et al., 2004; Ghaly et al., 2005).

\section{Preparation of yeast inocula}

The $S c$ yeast were of strain ATCC-13507 from the microbiology laboratory of Facultad de Medicina Veterinaria of Universidad Católica de Temuco (Temuco, Chile). To ensure a homogeneous $S c$ dosage, a standard solution with spores of $S c$ was generated. The inocula of $S c$ were incubated for 4 days at $28{ }^{\circ} \mathrm{C}$ in Petri dishes using potato dextrose agar (PDA) as the propagation substrate. The incubation-elapsed spores were extracted from the dish and aggregated in a 125$\mathrm{mL}$ beaker that contained $10 \mathrm{~mL}$ distilled water. The number of spores was then counted using a hemocytometer (Neubauer). Finally, a standard solution with a concentration of $6.7 \times 10^{6}$ spores $\mathrm{mL}^{-1}$ was established.

\section{Collection and preparation of substrates}

Five substrates were evaluated, of which four were fibrous: 1) wheat straw: WS (Triticum aestivum); 2) barley straw: BS (Hordeum vulgare); 3) chili stubble: CS (Capsicum annuum); and 4) oats hull: $\mathrm{OH}$ (Avena sativa). The fifth treatment corresponded to the control, which consisted of starch-glucose powder: SP (Riedel-deHaën 33615-7111A and Riedel-deHaën 16301-72720, respectively for starch and glucose). The fibrous substrates (WS, BS and CS) were collected from crops (stubble) in the IX Region. In the field, these substrates were selected with care not to take those plants with wounds, with signs of phytopathogenic disease or with dirt or other impurities. $\mathrm{OH}$ was provided by a company in the Araucanía 
Region and corresponded to a byproduct of the industrialization of oats for animal and human intake. Of each substrate, 5 subsamples (500 g) were collected and subsequently mixed. All of the samples were washed in the laboratory with distilled water for $15 \mathrm{~min}$, autoclaved at $121^{\circ} \mathrm{C}$ for $20 \mathrm{~min}$ and dried at $60^{\circ} \mathrm{C}$ for $48 \mathrm{~h}$ in a stove. The substrates were later chopped to $0.1-0.3 \mathrm{~cm}$.

\section{Yeast incubation with the substrates}

Erlenmeyer flasks $(250 \mathrm{~mL})$ were used as a bioreactor and were fitted with a rubber and glass device in such way to allow for aerobic conditions and avoid microbiological contamination. The Erlenmeyer flasks were sterilized with UV radiation (Laminar Flow Cabinet: STREAMLINE SHC-4A1) for $30 \mathrm{~min}$. Before sterilization, these flasks were treated (cleaned) with alcohol $(98 \%)$. The incubation time was 7 days at $26^{\circ} \mathrm{C}$. Each culture was composed of $2 \mathrm{~g}$ dry substrate (for the TSP treatment, $1 \mathrm{~g}$ starch and $1 \mathrm{~g}$ glucose were mixed) added to $12 \mathrm{~mL}$ incubation medium, which constituted $8 \mathrm{~mL}$ buffer Tris $50 \mathrm{Mm}(\mathrm{pH}$ 5), $2 \mathrm{~mL}$ streptomycin antibiotic solution (0.5 g $500 \mathrm{~mL}^{-1}$ distilled water) to prevent bacterial contamination, $1 \mathrm{~mL}$ urea to $5 \%(\mathrm{w} / \mathrm{v})$ and 1 $\mathrm{mL}$ of peptone to $2 \%$ (Ruiz et al., 2012). The $S c$ inoculation dose consisted of $2 \mathrm{~mL} \mathrm{flask}^{-1}$ of a solution of $6.7 \times 10^{6}$ spores $\mathrm{mL}^{-1}$.

\section{Extraction of yeast biomass}

To stop $S c$ growth and prepare the aqueous medium to initiate the separation of cellular biomass from the substrates (at the end of the incubation), $150 \mathrm{~mL}$ distilled water $\left(2^{\circ} \mathrm{C}\right)$ was added to each Erlenmeyer flask. The total contents of the bioreactors were homogenized by blending ( $3 \mathrm{~min}$ ) (Waring 8010BU-CAC33) and filtered through cheesecloth, followed by a second filtration through a steel mesh with a pore size of $100 \mu \mathrm{m}$. The filtrate was then centrifuged at 6,500 $\mathrm{x} g(10$ min) at $4{ }^{\circ} \mathrm{C}$, obtaining a pellet corresponding to the yeast biomass (Velásquez et al., 2012). This protein concentrate was frozen at $-32^{\circ} \mathrm{C}$ until the in vitro digestibility of its proteins was assayed.

\section{Determination of the chemical composition of} the substrates and yeast biomass

A bromatological analysis was performed on the vegetable substrates (WS, $\mathrm{BS}, \mathrm{CS}, \mathrm{OH}$, and $\mathrm{SP}$ ) and generated $S c$ biomass. Using the official method, the contents of dry matter (DM) (934.01), ash (942.05), crude fiber (CF) (978.10) and N (984.13) were determined according to AOAC (1990). The plant cell wall or neutral detergent fiber (NDF) and acid detergent fiber (ADF) were measured via the method of Van Soest et al. (1991). These fibrous fractions were determined without alpha amylase and were expressed exclusive of residual ash. The true protein (TP) content was determined from the buffer-insoluble $\mathrm{N}$ plus the ratio of insoluble $\mathrm{N}$ in trichloroacetic acid (TCA) to soluble $\mathrm{N}$ in the buffer. The soluble N (SN) was determined by the micro-Kjeldahl method from the $\mathrm{N}$ contents of the supernatants after the centrifugation of a sample at $12,000 \mathrm{x} g$ for $20 \mathrm{~min}$ (Shou-Wei et al., 2008). The Kjeldahl $\mathrm{N}$ was measured in the fiber residues to determine the insoluble $\mathrm{N}$ in neutral detergent fiber (NDIN) and insoluble $\mathrm{N}$ in acid detergent fiber (ADIN). Each treatment was corrected with the respective blanks, consisting of incubations of the substrates without inocula $(S c)$. Furthermore, the basal input of inoculum by incubation of yeast ( $S c$ spores) in the culture medium was corrected using an inert material without organic substrate (Velásquez et al., 2012).

Effect of type of substrate fermented by $S$. cerevisiae on the in vitro digestibility of crude and true protein in the yeast biomass

Once the $S c$ biomass pellets were obtained for each treatment, the in vitro digestibility of the $\mathrm{CP}$ $\left(\mathrm{D}_{\text {ivcp }}\right), \mathrm{CP}$ at $2 \mathrm{~h}\left(\mathrm{D}_{\mathrm{iv} 2 \mathrm{~h}}\right), \mathrm{TP}\left(\mathrm{D}_{\mathrm{tp}}\right)$ and hydrolysis rate of $\mathrm{CP}\left(k d_{c p}\right)$ in the generated yeast biomass 
was measured, simulating the digestive conditions of a monogastric animal. To do this, 0.5 -g samples of the $S c$ biomass were incubated at $37^{\circ} \mathrm{C}$ in 9.5 $\mathrm{mL}$ of a solution of $0.1 \mathrm{M} \mathrm{HCl}(\mathrm{pH}$ ) plus pepsin (Merck: EC 34231-107185.0100), with an activity of 0.7 FIP-U mg ${ }^{-1}$ and an enzyme substrate ${ }^{-1}$ ratio of $1: 100(\mathrm{w} / \mathrm{w})$. After acid digestion, the solution was digested with trypsin (Calbiochem: EC 34214-18002220342) at a dose of 1:100 (w/w) with an activity of $3894 \mathrm{U} \mathrm{mL}^{-1}$ plus pancreatin from porcine pancreas (Merck: 1071301000), which contains a mixture of hydrolytic enzymes. The activities of the enzymes in this mixture were 350 FIP-U g ${ }^{-1}, 6000$ FIP-U g ${ }^{-1}$ and 7500 FIP-U $\mathrm{g}^{-1}$ (protease, lipase and amylase, respectively). One FIP unit is the amount of enzyme that hydrolyzes casein under standard conditions, expressed as equivalent micromoles of tyrosine liberated per minute at $25{ }^{\circ} \mathrm{C}$. The dose of this mixture (pancreatin) corresponded to an enzyme substrate $^{-1}$ ratio of 1:70 $(\mathrm{w} / \mathrm{w})$. It was determined in previous experiments that the doses indicated above ensure first-order kinesis under substratelimiting conditions. To initiate this second phase of digestion, the incubation from the first phase was mixed with the trypsin enzyme mixture plus pancreatin in a phosphate buffer solution (pH 7) at $37^{\circ} \mathrm{C}$ (Nakornpanom et al., 2010). The incubation times were $0,1,2,4,6,8,10,12$ and $14 \mathrm{~h}$ (only for second phase digestion: trypsin + pancreatin). For the acid digestion (pepsin), a 2-h longer digestion time was used for all of the kinetic times zero (Wilfart et al., 2008). Next, the $\mathrm{D}_{\text {ivcp}}$, $\mathrm{D}_{\mathrm{iv} 2 \mathrm{~h}}, \mathrm{D}_{\mathrm{tp}}$ and $k d_{c p}$ parameters were calculated.

To quantify protein degradation after filtration in a vacuum with Whatman $\mathrm{N}^{\circ} 41$ paper, the Nsoluble TCA content (for each kinetic time) was measured by the micro-Kjeldahl method $(\mathrm{N} \times$ $6.25)$. For this measurement, a sample of $1.0 \mathrm{~mL}$ filtrate was taken and added to an Eppendorf tube containing $150 \mu \mathrm{L}$ TCA. This tube was refrigerated at $4{ }^{\circ} \mathrm{C}$ for $30 \mathrm{~min}$ and then centrifuged at $21,690 \times$ g at $4{ }^{\circ} \mathrm{C}$ for $20 \mathrm{~min}$. The TCA-soluble $\mathrm{N}$ from the sample was determined by the supernatant. Then, $\mathrm{D}_{\text {ivcp }}$ and $\mathrm{D}_{\mathrm{iv} 2 \mathrm{~h}}$ were determined by quantifying the TCA-soluble $\mathrm{N}$ at 14 and $2 \mathrm{~h}$ of incubation (divided by the total $\mathrm{N}$ of the sample) $\times 100$, respectively. The same procedure was performed for all other kinetic times. The $\mathrm{D}_{\mathrm{tp}}$ was determined by the quantification of TCA-soluble $\mathrm{N}$ at $14 \mathrm{~h}$ minus TCA-soluble $\mathrm{N}$ at 0 time, divided by total $\mathrm{N} \times 100$ (Shou-Wei et al., 2008). A blank (no enzymes) was considered for all of the assays. These blank samples allowed for the correction of $\mathrm{N}$ content of the enzymes (Wilfart et al., 2008).

The fractional hydrolysis rate $\left(k d_{c p}\right)$ was calculated by linear regression during the exponential phase of the protein breakdown curves ( $\ln y=a$ $+b x$ ), where $y$ corresponds to the percentage of degraded $\mathrm{CP}, b$ to the fractional rate of proteolysis $\left(k d_{c p}\right)$ and $\times$ to the incubation time. For each dynamic degradation (treatment), a kinetic curve (non-linear regression) was fitted by iteration using the computer program CurveExpert Version 1.38: 2001. Daniel G. Hyams, Tennessee, USA.

\section{Experimental design and statistical analysis}

A completely random experimental design was used in this experiment, with the type of substrate fermented by $S c$ yeast as the factor of study. The experiment was repeated three times, each time in triplicate. The experimental unit (EU) was an Erlenmeyer flask containing the sample of yeast biomass that was subjected to in vitro digestion. The statistical model was $Y_{i j}=\mu+\alpha_{i}+\varepsilon_{i j}$, where $\mathrm{Y}_{\mathrm{ij}}=$ observed value $\left(\mathrm{D}_{\mathrm{ivcp}} ; \mathrm{D}_{\mathrm{iv} 2 \mathrm{~h}} ; \mathrm{D}_{\mathrm{tp}}\right.$ and $\left.k d_{c p}\right)$ for the $\mathrm{i}^{\text {th }}$ treatment and $\mathrm{j}^{\text {th }}$ observation, $\mu=$ general mean and $\alpha_{i}=$ effect of the $i^{\text {th }}$ treatment (type of substrate). The treatments included TWS (wheat straw substrate), TBS (barley straw substrate), TCS (chili stubble substrate), TOH (oats hull substrate) and TSP (starch-glucose powder substrate (control)); $\varepsilon_{\mathrm{ij}}=$ experimental error of the $\mathrm{i}^{\text {th }}$ treatment and $\mathrm{j}^{\text {th }}$ observation. Differences were considered significant when $P \leq 0.05$. The statistical hypotheses were tested by a one-way ANOVA, and the treatment means were compared by Tukey's test (5\% level of significance). The data were 
analyzed using the software SYSTAT 11: 2003, Leland Wilkinson, Chicago, USA and JMP ${ }^{\circledR}$, version 5.0.1.2: 2003, SAS Inc., Cary, NC USA.

\section{Results}

The results indicate an effect $(\mathrm{P} \leq 0.001)$ of the type of substrate fermented by $S c$ on the magnitude of $\mathrm{D}_{\text {ivcp }}$ in the yeast biomass (Table 1). The greatest digestibility was obtained with TSP $(78.9 \% \mathrm{CP})$. The treatments TWS, TBS and TOH showed no differences $(\mathrm{P}>0.05)$ in the $\mathrm{D}_{\text {ivcp }}$ measurement, with an average of $71 \% \mathrm{CP}$. The lowest value for $\mathrm{D}_{\text {ivcp }}$ was measured in TCS $(67.1 \% \mathrm{CP})$. For $\mathrm{D}_{\text {iv2h }}$, there were differences between treatments $(\mathrm{P} \leq 0.001)$. However, TWS, TBS, TOH and TSP were not different ( $\mathrm{P}>0.05$ ), averaging $29.3 \% \mathrm{CP}$ degradation after $2 \mathrm{~h}$ of incubation. The lowest value for this parameter was measured in the TCS treatment $(23 \% \mathrm{CP})$. For $\mathrm{D}_{\mathrm{tp}}$, an effect of substrate on its magnitude was observed $(\mathrm{P} \leq 0.01)$. The highest value was measured in TSP $(64 \% \mathrm{CP})$. TWS, TBS and TOH were statistically equal, exhibiting an average of $57 \% \mathrm{CP}$. TCS showed the lowest value $(51.3 \% \mathrm{CP})$, which is consistent with the least amount of $\mathrm{D}_{\text {ivcp }}$ exhibited by this treatment.

In terms of degradation rates $\left(k d_{c p}\right)$, the results showed an effect $(\mathrm{P} \leq 0.01)$ of the type of substrate fermented on this kinetic parameter. TSP showed the highest value $\left(18.4 \% \mathrm{~h}^{-1}\right)$. The TWS, TBS and
TOH treatments were not different $(\mathrm{P}>0.05)$, averaging $16.4 \% \mathrm{~h}^{-1}$. The lowest rate of degradation was measured in TCS and was equal to $14.7 \% \mathrm{~h}^{-1}$.

Figure 1 graphically shows the abovementioned kinetic parameters. Additionally, it shows the magnitude of TCA-soluble $\mathrm{N}$ in the treatments at time zero, indicating the instantaneous solubility of $\mathrm{N}$ at the beginning of the experiment. From this kinetic time, the $\mathrm{D}_{\text {tp }}$ can be identified and culminates asymptotically for each treatment. Additionally, it is clearly possible to identify the $\mathrm{D}_{\text {ivcp }}$ levels, highlighting the TSP treatment, which showed the greatest magnitude of this parameter and the highest $\mathrm{CP}$ degradation rate. The lowest value for both of these parameters was in the TCS treatment.

Another aspect to consider is the fact that the protein digestibility peaked (asymptotic) in all of the treatments, starting from 8 hours of incubation. This pattern allows us to conclude that the digestibility of proteins is most active early in the digestion process.

\section{Discussion}

When $S c$ fermented different substrates, the produced yeast biomass showed significant differences in $\mathrm{D}_{\text {ivcp }}, \mathrm{D}_{\mathrm{iv} 2 \mathrm{~h}}, \mathrm{D}_{\mathrm{tp}}$ and $k d_{c p}$, despite having the same microbiological origin (axenic culture).

Table 1. Effect of the type substrate fermented on the in vitro digestibility of crude and true protein of Saccharomyces cerevisiae extract.

\begin{tabular}{|c|c|c|c|c|c|c|c|}
\hline \multirow[b]{2}{*}{ Kinetic parameter } & \multicolumn{6}{|c|}{ Yeast protein extract } & \multirow[b]{2}{*}{$\mathrm{P}$} \\
\hline & TWS $^{1}$ & TBS & TCS & $\mathrm{TOH}$ & TSP & SEM & \\
\hline $\mathrm{D}_{\mathrm{ivcp}}^{2}(\% \mathrm{CP})$ & $71.2 \mathrm{~b}$ & $70.5 \mathrm{~b}$ & $67.1 \mathrm{c}$ & $71.3 b$ & $78.9 \mathrm{a}$ & 0.63 & $\leq 0.001$ \\
\hline $\mathrm{D}_{\mathrm{iv} 2 \mathrm{~h}}(\% \mathrm{CP})$ & $29.8 \mathrm{a}$ & $28.4 \mathrm{a}$ & $23.0 \mathrm{~b}$ & $28.7 \mathrm{a}$ & $30.1 \mathrm{a}$ & 0.41 & $\leq 0.001$ \\
\hline $\mathrm{D}_{\mathrm{tp}}(\% \mathrm{CP})$ & $56.9 \mathrm{~b}$ & $56.8 \mathrm{~b}$ & $51.3 \mathrm{c}$ & $57.2 \mathrm{~b}$ & $64.0 \mathrm{a}$ & 0.43 & $\leq 0.01$ \\
\hline $\mathrm{kd}_{\mathrm{cp}}\left(\% \mathrm{~h}^{-1}\right)$ & $16.8 \mathrm{~b}$ & $16.1 \mathrm{~b}$ & $14.7 \mathrm{c}$ & $16.2 \mathrm{~b}$ & $18.4 \mathrm{a}$ & 0.34 & $\leq 0.01$ \\
\hline
\end{tabular}

Different letters within rows indicate significant differences $(\mathrm{P} \leq 0.05)$.

'TWS: treatment with wheat straw substrate, TBS: barley straw substrate, TCS: chili stubble substrate, TOH: oats hull substrate, TSP: starch-glucose powder substrate.

${ }^{2} \mathrm{D}_{\text {ivcp }}$ : in vitro digestibility of crude protein $(\mathrm{CP})$ after $14 \mathrm{~h}$ of incubation, $\mathrm{D}_{\mathrm{iv} 2 \mathrm{~h}}$ : in vitro digestibility of $\mathrm{CP}$ at $2 \mathrm{~h}$, $\mathrm{D}_{\mathrm{tp}}:$ in vitro digestibility of true protein, $k d_{c p}$ : hydrolysis rate of CP. 
A possible explanation for this phenomenon may be the variation in the chemical composition of the digested yeast extract, as the digestibility of proteins depends, among others factors, on the extent and rate of degradation of the nitrogen fractions of the food, of the biochemical nature of the polypeptides (involving changes in enzyme substrate affinity) and of the susceptibility of proteins to the action of nucleophilic proteases. The digestibility also depends on the interaction between the peptides and other molecules or polymers that are present in the food, mainly the fibrous fractions that are located in the cell walls (Colombatto et al., 2007). Nevertheless, the observed differences in chemical composition between the evaluated treatments only occurred in the contents of $\mathrm{CP}$ and SN (Table 2). In the case of CP, the $\mathrm{CP}$ content in a food does not necessarily imply a greater or lesser extent and/or rate of protein degradation, considering substrate-limiting kinetic conditions (Velásquez and Pichard, 2010). It is more likely that the variations in the content and composition of the SN caused the observed variability between treatments because this nitrogen fraction may have contained a more- or less-soluble true protein mass, which is usually highly digestible. The greater $\mathrm{D}_{\mathrm{ivcp}}, \mathrm{D}_{\mathrm{tp}}$ and $k d_{c p}$ values that were observed in the TSP treatment may have been due to the higher $\mathrm{SN}$ concentration presented by the $S c$ biomass $(47.0 \% \mathrm{CP})$ when starch and glucose were fermented compared to the other evaluated substrates, whose average to $\mathrm{SN}$ was $43.2 \%$ CP (Table 2). While the TCS treatment did not show a different $\mathrm{SN}$ content from that of the other treatments with fibrous substrates, the lowest extent and rate of protein degradation may be due to a lower soluble true protein content, possibly influenced by the higher fiber content (CF, NDF, and ADF) and/or N-linked to fibrous residues (NDIN and ADIN) present in CS (Table 3) at the time of fermentation by $S c$ during the generation of the protein extract. This phenomenon is based on the fact that the carbohydrate content in the culture medium during rapid fermentation is directly correlated with the synthesis of yeast proteins (Brejning and
Jespersen, 2002). Indeed, when $S c$ fermented a rapid fermentation substrate (starch-glucose), this yeast obtained a major source of energy and carbon skeletons as well as $\mathrm{N}$, implying favorable conditions for cell growth and reproduction. This situation resulted in a greater microbial protein synthesis (indirectly estimated through the chemical composition of the yeast extract), with the possibility of increasing the amount of soluble true protein of high digestibility. Although the biochemical nature of the proteins of the yeast extracts in this research has not been examined, there most likely existed some degree of variation in the molecular weight distribution, biological function and physical-chemical susceptibility to proteolytic action of the polypeptides that were present in the different treatments, which may have contributed to the observed variation in the kinetic parameters.

The observed results are supported by existing levels of association between the $\mathrm{CP}$ and $\mathrm{TP}$ contents (Table 3 ) of the substrate and the in vitro digestibility values at $14 \mathrm{~h}$ of $\mathrm{CP}$ and TP of $\mathrm{Sc}$ extracts (Table 1). Indeed, the correlation coefficients reached values between -0.94 and -0.83 , as determined by the substrate $\mathrm{CP}$ content and $\mathrm{CP}$ digestibility of the $S c$ biomass and the substrate TP content and in vitro TP digestibility of the $S c$ biomass, respectively. These observations suggest that the fermented substrates are related to the quality of produced yeast protein.

The absence of differences in the chemical composition of the $S c$ biomass when the various substrates were fermented, in terms of CF, FDN, FDA, NDIN and ADIN (Table 2), allows us to discount a possible effect of the fibrous fractions as a result of their interacting with proteins during degradation. The determination of $D_{t p}$ allowed us to appreciate the magnitude of the digestibility of true protein (Table 1; Figure 1). Such information is valuable for non-ruminants, as the supply of essential amino acids in these animals is fundamentally from the diet. The $\mathrm{D}_{\mathrm{tp}}$ average, considering all of the treatments, was 
$57.2 \% \mathrm{CP}$, implying that approximately $26 \% \mathrm{DM}$ yeast extract (considering a $45 \% \mathrm{CP}$ content on average) will be available as degradable true protein. This value is interesting when the extract is considered a potential source of amino acids, due to the normally high biological value of the yeast protein (Rostami et al., 2009; Winkler et al., 2011).

There is no doubt that the levels of extension and the protein degradation rates that were achieved by the different fibrous substrate treatments are auspicious. An in vitro digestibility of $\mathrm{CP}$ in excess of $70 \%$, with degradation rates close to $16 \% \mathrm{~h}^{-1}$, suggests that this $S c$ biomass has the potential to become an alternative protein supplement with a high nutritional value. Additionally, the low

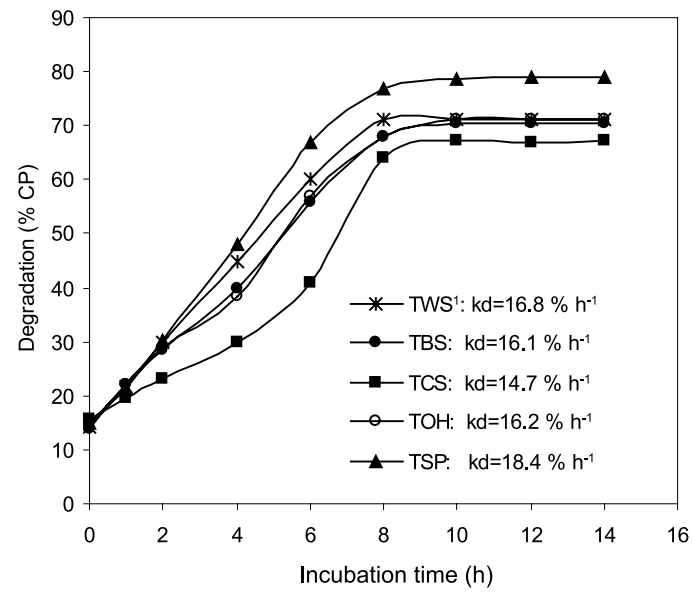

Figure 1. Effect of substrate on the in vitro crude protein (CP) degradation of extracts that were generated by Saccharomyces cerevisiae.

${ }^{1}$ TWS: treatment with wheat straw substrate, TBS: barley straw substrate, TCS: chili stubble substrate, TOH: oats hull substrate, TSP: starch-glucose powder substrate, $k d$ : hydrolysis rate of crude protein $\left(k d_{c p}\right)$.

Table 2. Chemical composition of Saccharomyces cerevisiae protein extract.

\begin{tabular}{|c|c|c|c|c|c|c|c|}
\hline \multirow{2}{*}{$\begin{array}{l}\text { Chemical } \\
\text { composition }\end{array}$} & \multicolumn{6}{|c|}{ Yeast protein extract } & \multirow[b]{2}{*}{$\mathrm{P}$} \\
\hline & TWS $^{1}$ & TBS & TCS & $\mathrm{TOH}$ & TSP & SEM & \\
\hline $\mathrm{CP}^{2}(\% \mathrm{DM})$ & $43.6 c^{5}$ & $44.2 \mathrm{c}$ & $38.3 \mathrm{~d}$ & $47.2 \mathrm{~b}$ & $51.1 \mathrm{a}$ & 0.61 & $\leq 0.01$ \\
\hline $\mathrm{TP}(\% \mathrm{CP})$ & 85.7 & 86.3 & 84.2 & 85.9 & 85.1 & 1.36 & 0.11 \\
\hline $\mathrm{SN}(\% \mathrm{CP})$ & $43.2 \mathrm{~b}$ & $43.0 \mathrm{~b}$ & $43.4 \mathrm{~b}$ & $43.3 \mathrm{~b}$ & $47.0 \mathrm{a}$ & 0.52 & $\leq 0.05$ \\
\hline $\mathrm{CF}(\% \mathrm{DM})$ & 2.9 & 3.1 & 2.8 & 2.7 & 2.9 & 0.03 & 0.18 \\
\hline $\mathrm{NDF}^{3}(\% \mathrm{DM})$ & 22.1 & 22.3 & 22.7 & 22.8 & 22.4 & 0.27 & 0.23 \\
\hline $\mathrm{ADF}(\% \mathrm{DM})$ & 5.8 & 6.3 & 5.8 & 5.6 & 5.8 & 0.09 & 0.19 \\
\hline $\operatorname{NDIN}^{4}(\% \mathrm{CP})$ & 8.6 & 8.9 & 9.0 & 8.6 & 9.2 & 0.11 & 0.28 \\
\hline ADIN (\% CP) & 3.5 & 3.6 & 3.4 & 3.6 & 3.7 & 0.06 & 0.25 \\
\hline
\end{tabular}

Distinct letters within rows indicate significant differences $(\mathrm{P} \leq 0.05)$.

${ }^{1}$ TWS: concentrate wheat straw substrate, TBS: barley straw substrate, TCS: chili stubble substrate, TOH: oats hull substrate, TSP: starch-glucose powder substrate.

${ }^{2} \mathrm{CP}$ : crude protein, TP: true protein, $\mathrm{SN}$ : $\mathrm{N}$ soluble fraction, $\mathrm{CF}$ : crude fiber.

${ }^{3} \mathrm{NDF}$ : neutral detergent fiber, ADF: acid detergent fiber.

${ }^{4} \mathrm{NDIN}$ : insoluble $\mathrm{N}$ in neutral detergent, ADIN: insoluble $\mathrm{N}$ in acid detergent.

${ }^{5}$ Chemical assay of three samples.

Table 3. Chemical composition of vegetable substrates.

\begin{tabular}{|c|c|c|c|c|c|c|c|c|c|c|}
\hline Substrate $^{1}$ & $\begin{array}{c}\mathrm{DM}^{2} \\
\% \\
\end{array}$ & $\begin{array}{c}\text { Ash } \\
\% \text { DM }\end{array}$ & $\begin{array}{c}\mathrm{CP} \\
\% \mathrm{DM} \\
\end{array}$ & $\begin{array}{c}\text { CF } \\
\% \mathrm{DM} \\
\end{array}$ & $\begin{array}{c}\mathrm{NDF}^{3} \\
\% \mathrm{DM}\end{array}$ & $\begin{array}{c}\mathrm{ADF} \\
\% \mathrm{DM}\end{array}$ & $\begin{array}{c}\mathrm{TP}^{4} \\
\% \mathrm{CP} \\
\end{array}$ & $\begin{array}{c}\mathrm{SN} \\
\% \mathrm{CP}\end{array}$ & $\begin{array}{l}\mathrm{NDIN}^{5} \\
\% \mathrm{CP} \\
\end{array}$ & $\begin{array}{l}\text { ADIN } \\
\% \mathrm{CP} \\
\end{array}$ \\
\hline WS & $97.2^{6}$ & 8.2 & 4.1 & 43.4 & 86.9 & 55.6 & 89.8 & 22.8 & 29.7 & 16.6 \\
\hline BS & 97.0 & 9.8 & 4.5 & 41.1 & 85.0 & 54.8 & 90.5 & 23.2 & 28.4 & 16.4 \\
\hline $\mathrm{CS}$ & 96.8 & 7.1 & 4.8 & 51.7 & 87.5 & 66.2 & 88.7 & 18.3 & 30.5 & 17.9 \\
\hline $\mathrm{OH}$ & 97.8 & 9.7 & 4.6 & 33,2 & 76.0 & 42.0 & 85.6 & 22.4 & 25.8 & 9.8 \\
\hline SP & 98.4 & 2.0 & 0 & 0 & 0 & 0 & 0 & 0 & 0 & 0 \\
\hline
\end{tabular}

${ }^{1} \mathrm{WS}$ : wheat straw, BS: barley straw, CS: chili stubble, OH: oats hull, SP: starch-glucose powder.

${ }^{2} \mathrm{DM}$ : dry matter, CP: crude protein, $\mathrm{CF}$ : crude fiber.

${ }^{3} \mathrm{NDF}$ : neutral detergent fiber, ADF: acid detergent fiber.

${ }^{4} \mathrm{TP}$ : true protein, $\mathrm{SN}$ : N soluble fraction.

${ }^{5} \mathrm{NDIN}$ : insoluble $\mathrm{N}$ in neutral detergent, ADIN: insoluble $\mathrm{N}$ in acid detergent.

${ }^{6} \mathrm{Chemical}$ assay of three samples. 
average values of $\mathrm{CF}$, NDF, AFD, NDIN and ADIN that were observed in the $S c$ extract when the fibrous substrates were fermented allow us to suppose that in vivo digestibility levels that are well above those measured in this research are achievable.

\section{Acknowledgments}

Thanks are due to Ing. Agr. MSc. María Isabel Martínez for the collaboration in the laboratory experiments. This project was funded by DGIP 2009308 of Universidad Católica de Temuco (Chile).

\title{
Resumen
}

\begin{abstract}
A. Velásquez, and R. Arias. 2013. Efecto del tipo de sustrato sobre la digestibilidad in vitro de la proteína de extractos generados por Saccharomyces cerevisiae. Cien. Inv. Agr. 40(3): 503-511. Se evaluó el efecto del tipo de sustrato a fermentar por Saccharomyces cerevisiae $(S c)$ sobre la digestibilidad in vitro de la proteína cruda $\left(\mathrm{D}_{\mathrm{ivcp}}\right.$ y $\left.\mathrm{D}_{\mathrm{iv2h}}\right)$, de la proteína verdadera $\left(\mathrm{D}_{\mathrm{tp}}\right)$ y la tasa de degradación de proteína $\left(k d_{c p}\right)$ en diferentes extractos proteicos producidos por esta levadura. Estos fueron generados a través de un método biotecnológico (fermentación en estado sólido). Se utilizaron como sustratos (tratamientos del experimento) paja de trigo, TWS; paja de cebada, TBS; rastrojo de ají, TCS; cáscara de avena, TOH y almidón-glucosa en polvo, TSP (control). Para el cultivo de $S c$ con los sustratos a evaluar, se agregaron $2 \mathrm{~mL}$ de una solución de inóculo de $S c\left(6,7 \times 10^{6}\right.$ sporas $\left.\mathrm{mL}^{-1}\right)$ a $12 \mathrm{~mL}$ de medio de cultivo, junto con $2 \mathrm{~g}$ de sustrato vegetal (materia seca), más una fuente de nitrógeno. La incubación fue mantenida por 7 días bajo condición aeróbica, a una temperatura constante de $26^{\circ} \mathrm{C}(\mathrm{pH}$ 5). El contenido promedio de PC de la biomasa de levadura generada fue de $45 \%$. Luego de realizar la extracción de la biomasa de $S c$, se midió la digestibilidad in vitro de sus proteínas en dos fases (pepsina/tripsina-pancreatina). Los resultados permitieron observar un efecto del tipo de sustrato fermentado $(P \leq 0,001)$ sobre la $\mathrm{D}_{\text {ivcp }}$ y $\mathrm{D}_{\text {tp }}(\mathrm{P} \leq 0,01)$. La mayor digestibilidad $\left(\mathrm{D}_{\text {ivcp}}\right)$ fue obtenida con TSP $(78,9 \%$ PC) y la menor con TCS $(67,1 \%$ PC). También, se pudo apreciar diferencias entre los tratamientos $(\mathrm{P} \leq 0,01)$ para la velocidad de degradación $\left(k d_{c p}\right)$. La medición de un $71,8 \%$ (promedio) para $\mathrm{D}_{\text {ivcp }}, 16,4 \% \mathrm{~h}^{-1}$ (promedio) para $k d_{c p}$, y un contenido satisfactorio de PC, permiten sugerir que este extracto de $S c$ posee el potencial para llegar a constituir una alternativa como suplemento proteico para nutrición animal.
\end{abstract}

Palabras clave: Digestibilidad de proteína in vitro, extracto de proteínas, Saccharomyces cerevisiae, sustratos vegetales.

\section{References}

AOAC. 1990. Association of Official Analytical Chemists. Official Methods of Analysis, $15^{\text {th }}$ Edition. Washington DC, USA.

Brejning, J., and L. Jespersen. 2002. Protein expression during lag phase and growth initiation in Saccharomyces cerevisiae. Int. J. Food Microb. 75:27-38.

Colombatto, D., F.L. Mould, M.K. Bhat, and E. Owen. 2007. Influence of exogenous fibrolytic enzyme level and incubation $\mathrm{pH}$ on the in vitro ruminal fermentation of alfalfa stems. Anim. Feed Sci.Tech. 137:150-162.

Ferreira, I., O. Pinho, E. Vieira, and J. Tavarela. 2010. Brewer's Saccharomyces yeast biomass: characteristics and potential applications. Trends in Food Sc. \& Tech. 21:77-84.

Ghaly, A., M. Kamal, and L.R. Correia. 2005. Kinetic modelling of continuous submerged fermentation of cheese whey for single cell protein production. Biores. Tech. 96:1143-1152. 
Ghorai, S., S.P. Banik, D. Verma, S. Chowdhury, S. Mukherjee, and S. Khowala. 2009. Fungal biotechnology in food and feed processing. Food Res. Inter. 42:577-587.

Golfinopoulos, A., N. Kopsahelis, K. Tsaousi, A.A. Koutinas, and M. Soupioni. 2011. Research perspectives and role of lactose uptake rate revealed by its study using 14C-labelled lactose in whey fermentation. Biores. Tech.102:4204-4209.

Jay, J.M. 2000. Modern Food Microbiology. $6^{\circ}$ edition. An Aspen Pub. 679 pp.

Jung, E.Y., H.S. Lee, U.J. Chang, S.H. Bae, K.H. Kwon, and H.J. Suh. 2010. Acute and subacute toxicity of yeast hydrolysate from Saccharomyces cerevisiae. Food and Chem. Toxic. 48:1677-1681.

Mitchell, D.A., F. Oscar, N. von Meien, N. Krieger, and F.D. Dalsenter. 2004. A review of recent developments in modeling of microbial growth kinetics and intraparticle phenomena in solid-state fermentation. Bioch. Eng. J. 17:15-26.

Najafpour, G.D. 2007. Single-Cell Protein. Biochemical Engineering and Biotech. Amsterdam, Elsevier. p. 332-341.

Nakornpanom, N.N., P. Hongsprabhas, and P. Hongsprabhas. 2010. Effect of soy residue (okara) on in vitro protein digestibility and oil release in high-calorie emulsion stabilized by heated mixed proteins. Food Res. Inter. 43:26-32.

NRC. 2001. National Research Council. The online Books Page: National Research Council Committee on Animal Nutrition, United States-Canadian, Tables of Feed Composition. Washington, DC, USA.

Riasi, A., M.D. Mesgaran, M.D. Stern, and M.J. Ruiz. 2008. Chemical composition, in situ ruminal degradability and post-ruminal disappearance of dry matter and crude protein from the halophytic plants Kochia scoparia, Atriplex dimorphoste- gia, Suaeda arcuata and Gamanthus gamacarpus. Anim. Feed Sci. Tech. 141:209-219.

Rostami, K., M. Moazed, D. Zareh, A. Kheirolomoom. 2009. Single cell protein production using airlift reactor containing static mixer. J. Biosci. Bioeng. 108:S1, 136.

Ruiz, H.A., D.P. Silva, D.S. Ruzene, L.F. Lima, A.A. Vicente, and J.A. Teixeira. 2012. Bioethanol production from hydrothermal pretreated wheat straw by a flocculating Saccharomyces cerevisiae strain - Effect of process conditions. Fuel. 95:528-536.

Shou-Wei, Y., C. Tang, Q. Wen, X. Yang, and L. Li. 2008. Functional properties and in vitro trypsin digestibility of red kidney bean (Phaseolus vulgaris L.) protein isolate: Effect of high-pressure treatment. Food Chemistry 110:938-945.

Van Soest, P.J., J.B. Robertson, and B.A. Lewis. 1991. Methods for dietary fiber, neutral detergent fiber, and nonstarch polysaccharides in relation to animal nutrition. J. Dairy Sci. 74:3583-3597.

Velásquez, A., and G. Pichard. 2010. Effects of rumen fluid pre-incubation on in vitro proteolytic activity of enzymatic extracts from rumen microorganisms. Anim. Feed Sci. Tech. 162:75-82.

Velásquez, A., R. Arias, and M. Toneatti. 2012. Effect of the type of substrate on the chemical composition and productivity of a protein concentrate of yeast origin. Cien. Inv. Agr. 39:425-434.

Wilfart, A., Y. Jaguelin-Peyraud, H. Simmins, J. Noblet, J. van Milgen, and L. Montagne. 2008. Kinetics of enzymatic digestion of feeds as estimated by a stepwise in vitro method. Animal Feed Science and Technology 141:171-183.

Winkler, B., H. Tosi, A.J. Webster, F.D. Resende, A.A. Oliveira, and L.C. Villela. 2011. Dried yeast (Saccharomyces cerevisae) as a protein source for horses. Livestock Sci. 137:168-177. 
